\title{
Sward structure of marandu palisadegrass subjected to continuous stocking and nitrogen-induced rhythms of growth
} \author{
Olegário Caminha²; Vitor Del'Álamo Guarda²; Priscila de Mesquita Pereira² \\ ${ }^{1}$ USP/ESALQ - Depto. de Zootecnia, C.P. 09 - 13418-900 - Piracicaba, SP - Brasil. \\ ${ }^{2}$ USP/ESALQ - Programa de Pós-Graduação em Ciência Animal e Pastagens. \\ *Corresponding author <scdsilva@esalq.usp.br>
}

Lilian Elgalise Techio Pereira²; Adenilson José Paiva²; Sila Carneiro da Silva ${ }^{1 *}$; Fábio

\begin{abstract}
Acceleration of the growth rhythm of plants using nitrogen fertiliser alters the rates of physiological processes like growth and senescence and may cause significant changes in sward structure, interfering with plant and animal responses. The objective of this experiment was to evaluate sward structure of marandu palisadegrass (Brachiaria brizantha) maintained at $30 \mathrm{~cm}$ under continuous stocking and subjected to contrasting rhythms of growth from January 2007 to April 2008. These were generated using or not nitrogen fertiliser, and comprised four experimental treatments as follows: control (non-fertilised), 150, 300 and $450 \mathrm{~kg}$ $\mathrm{ha}^{-1}$ of $\mathrm{N}$. Acceleration of the growth rhythm of plants was associated with increases in leaf and stem bulk density, and resulted in larger LAI and total bulk density on swards subjected to faster (fertilised with 300 and 450 $\mathrm{kg} \mathrm{ha}^{-1}$ of N) than those subjected to slower rhythms of growth (non-fertilised or fertilised with $150 \mathrm{~kg} \mathrm{ha}^{-1}$ of $\mathrm{N})$. Variations in dead material bulk density were associated with seasonal variations in climatic conditions, and were not influenced by growth rhythms. During autumn/winter and early spring (dry period of the year) swards subjected to faster, relative to those subjected to slower rhythms of growth, had larger proportion of leaves on the top horizons. On the other hand, sward structure did not vary among rhythms of growth at times of the year when there was no limitation in the availability of climatic growth factors (late spring and summer), indicating that when control of the grazing process is efficient, changes in sward structure are basically a function of seasonal variations in climatic growth conditions and phenological state of plants.
\end{abstract}

Key words: herbage bulk density, morphological composition, grazing management, nitrogen

\section{Estrutura do dossel forrageiro de pastos de capim-marandu submetidos à lotação contínua e ritmos de crescimento induzidos por adubação nitrogenada}

\begin{abstract}
RESUMO: A aceleração do ritmo de crescimento das plantas por meio da adubação nitrogenada altera a velocidade dos processos fisiológicos, atuando sobre o crescimento e a senescência, podendo refletir-se em alterações importantes sobre a estrutura do dossel. Avaliou-se a estrutura do dossel forrageiro de pastos de capim-marandu (Brachiaria brizantha) mantidos a $30 \mathrm{~cm}$ de altura por meio de lotação contínua e submetidos a ritmos de crescimento contrastantes de janeiro de 2007 a abril de 2008. Os distintos ritmos de crescimento foram criados por meio da utilização de adubação nitrogenada, segundo os tratamentos: sem adubação (controle), 150, 300 e $450 \mathrm{~kg} \mathrm{ha}^{-1}$ de N. A aceleração do ritmo de crescimento dos pastos resultou em aumentos de densidade volumétrica de folhas e de colmos, refletindo em maior IAF e densidade volumétrica total em pastos submetidos aos ritmos de crescimento mais acelerados (adubados com 300 e $450 \mathrm{~kg} \mathrm{ha}^{-1} \mathrm{de} \mathrm{N}$ ) relativamente àqueles submetidos a ritmos de crescimento mais lentos (pastos não adubados e/ou adubados com $150 \mathrm{~kg} \mathrm{ha}^{-1}$ de N). Variações em densidade volumétrica do material morto estiveram associadas a flutuações estacionais das condições climáticas, e não foram influenciadas pelos ritmos de crescimento avaliados. Na época da seca (outono/inverno e início de primavera), os pastos submetidos aos ritmos de crescimento mais acelerados apresentaram maior proporção de folhas no horizonte superior do dossel. Por outro lado, a estrutura do dossel não variou entre os ritmos de crescimento nas épocas de maior disponibilidade de fatores de crescimento (final de primavera e verão), indicando que quando o controle do processo de pastejo é feito de maneira eficiente, mudanças em estrutura são função basicamente de variações estacionais em condições climáticas e estádio fenológico das plantas.

Palavras-chave: densidade volumétrica, composição morfológica do pasto, manejo do pastejo, nitrogênio
\end{abstract}

\section{Introduction}

Sward structure is defined as the arrangement and spatial distribution of above ground plant parts within their community. Both vertical and horizontal distribution are important because of the limited spatial range of plant-plant interactions, and because grazers select forage vertically and horizontally (Laca and Lemaire, 2000). Sward structure is the result of morphogenetic responses of both individual and population tillers and influences the rate at which resources are acquired by individual plants and by sward canopy (Laca and Lemaire, 2000). 
Factors such as grazing management, determinants of severity and frequency of defoliation, availability of environmental growth factors such as light, temperature and rainfall, as well as availability of soil nutrients affect significantly patterns of growth and development of individual plants, interfering with how fast the processes happen (growth rhythm). Among plant nutrients, provided that there is no other limiting nutrient, nitrogen is probably the most important affecting growth dynamics by interfering with tissue flows in plant communities, once it accelerates the rates of plant growth and development, increasing herbage accumulation and influencing sward structure (Duru and Ducroq, 2000; Gastal et al., 1992). As a result, in order to realise the benefits of management practices using nitrogen fertilisation to accelerate plant growth it is necessary to understand how it affects sward structure and its pattern of variation throughout the year.

Marandu palisadegrass (Brachiaria brizantha) is one of the most used tropical forage grass species in Brazil and little knowledge is available on its ecophysiological responses to nitrogen fertilisation and the corresponding effect on sward structure. Against that background, the objective of this experiment was to evaluate sward structure and its patterns of variation throughout the year on continuously stocked marandu palisadegrass maintained at $30 \mathrm{~cm}$ and subjected to nitrogen-induced rhythms of growth.

\section{Material and Methods}

The experiment was carried out in Piracicaba, state of São Paulo, Brazil (22 $42^{\prime}$ S, $47^{\circ} 37^{\prime} \mathrm{W}$ and $550 \mathrm{~m}$ a.s.l.), on a Brachiaria brizantha (Hochst ex A. Rich) Stapf. cv. Marandu pasture established in 2001 on a Eutric Kandiudalf. Average soil chemical characteristics (Raij et al., 1983) for the $0-20 \mathrm{~cm}$ layer were: $\mathrm{pH} \mathrm{CaCl}: 5.1$; $\mathrm{OM}=41 \mathrm{dg} \mathrm{dm^{-3 }}$; $\mathrm{P}$ (ion-exchange resin extraction method) $=62 \mathrm{mg} \mathrm{dm}^{-3} ; \mathrm{Ca}=60 \mathrm{mmol} \mathrm{dm}_{\mathrm{c}}^{-3} ; \mathrm{Mg}=16$ mmol $\mathrm{dm}^{-3} ; \mathrm{K}=6.4 \mathrm{mmol} \mathrm{dm}_{\mathrm{c}}^{-3} ; \mathrm{H}+\mathrm{Al}=44 \mathrm{mmol}_{c}$ $\mathrm{dm}^{-3}$; sum of bases $=82.5 \mathrm{mmol}_{\mathrm{c}} \mathrm{dm}^{-3}$; cation exchange capacity $=124.5 \mathrm{mmol}_{c} \mathrm{dm}^{-3}$; base saturation $=65.2 \%$.

Mean air temperature indicated that summer I (January to March, 2007), autumn (April to June, 2007), winter (July to September, 2007) and early spring (October to November, 2007) were relatively warmer, and rainfall data revealed that summer 1 was wetter and autumn, winter, spring and summer 2 (January to March, 2008, except January 2008) were drier than the 90-year average (1917 to 2007) (Figure 1).

The experimental area comprised four blocks containing four $1,200 \mathrm{~m}^{2}$ paddocks each. Prior to this study, it was used for a series of experiments on continuous stocking from 2001 to 2003 and another one on rotational stocking from 2004 to 2006 focussing on aspects of plant ecophysiology and grazing ecology. At the end of those experiments the area was kept under rotational stocking by beef cattle until March 2006 and then staged at 10 $\mathrm{cm}$ in April in preparation for the present experiment based on continuous stocking management. Management target was a sward surface height of $30 \mathrm{~cm}$, a condition that, based on the results of the previous series of experiments under continuous stocking (swards maintained at $10,20,30$ and $40 \mathrm{~cm}$ ), resulted in high herbage accumulation, high animal performance and productivity, but low utilisation efficiency of the produced herbage ( $\mathrm{Da}$ Silva and Nascimento Jr., 2007a).

Monitoring of sward surface height started soon after staging and was performed in a weekly basis until swards had reached around $20 \mathrm{~cm}$, when frequency of monitoring started to be made twice a week until the end of the experiment. A total of 100 readings per paddock were recorded using a sward stick (Barthram, 1985). These were taken along four transect lines arranged in a zigzag format (25 points per transect). A tolerance range of $\pm 10 \%$ was established for variations around the target (27 to 33 $\mathrm{cm}$ ), and as the lower limit of the range was reached, animals started to be placed on paddocks, from October 2006 onwards. Animals were added or removed from paddocks according to the need to maintain sward target relatively stable and around $30 \mathrm{~cm}$. Grazing was carried out by Nelore (Bos taurus indicus) and Canchim (5/8 Charolais (Bos taurus taurus) $\times 3 / 8$ Zebu (Bos taurus indicus)) heifers with an average initial body weight of 250 to 280 kg. Variation in sward surface height throughout the experiment remained within the pre-specified range $(30 \mathrm{~cm}$ $\pm 10 \%$ ), with an average of $29.7 \mathrm{~cm}$ varying from 27.8 to

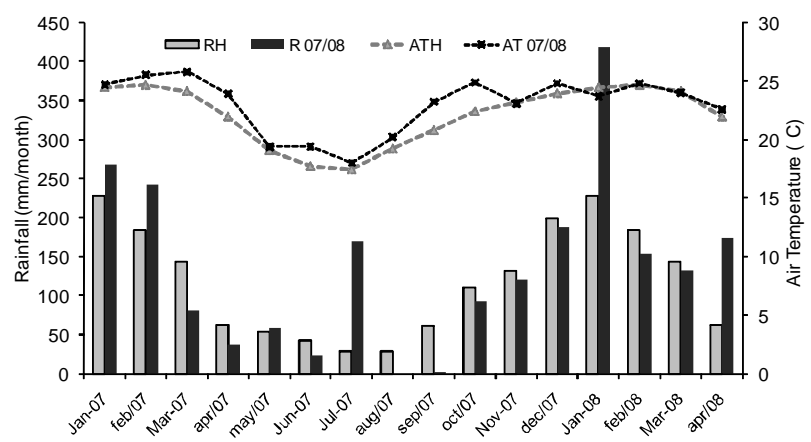

Figure 1 - Monthly (January 2007 to April 2008) and historical (H) (1917 to 2007) means of rainfall (R 07/08 and $\mathrm{RH}$, respectively) and air temperature (AT 07/08 and ATH, respectively) for the experimental site.

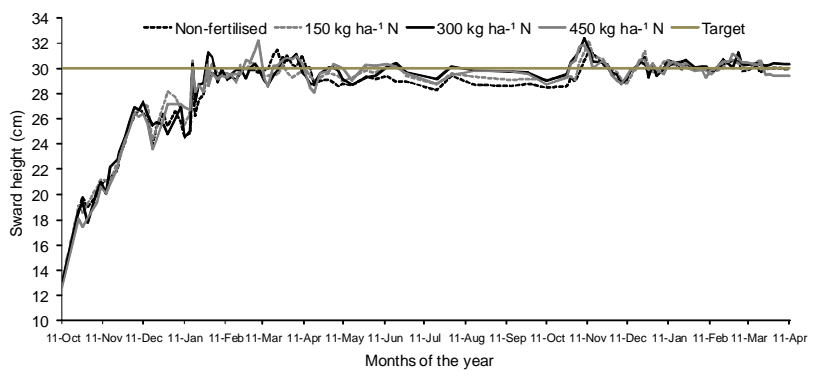

Figure 2 - Average swards surface height $(\mathrm{cm})$ of continuously stocked marandu palisadegrass from October, 2006 to April, 2008. 
$31.0 \mathrm{~cm}$ (Figure 2). Stocking rate used to control grazing and maintain swards on target varied from 0.3 to 5.6 animal units $\mathrm{ha}^{-1}$ (1 AU = one adult bovine weighing 450 $\mathrm{kg}$ ) throughout the year (Table 1).

Treatments corresponded to four rhythms of plant growth generated by the application of nitrogen fertiliser at the rates of 150,300 and $450 \mathrm{~kg} \mathrm{ha}^{-1}$ of $\mathrm{N}$ plus the control (no fertilisation). The nitrogen fertiliser used was pure ammonium nitrate. The total dose was applied in four equal instalments throughout the year in the following dates: Year 1 - December 19, 2006; January 16, 2007; February 23, 2007 and March 23, 2007; Year 2 - December 20, 2007; January 17, 2008; February 14, 2008 and March 13, 2008. The experimental design was a complete randomised block, with four replications. Experimental measurements were initiated after all 16 paddocks (experimental units) had reached the sward target of $30 \mathrm{~cm}$ and were being continuously stocked by cattle, a condition that only happened from December 2006 onwards. For that reason, the experimental period started only in January 2007 and finished in April 2008, comprising two entire consecutive pasture growing seasons (2006/2007 and 2007/2008).

Measurements of sward herbage mass, morphological composition and leaf area index were carried out throughout the experiment during five seasons of the year. These were defined based on the results from the previous series of experiments and corresponded to seasons within which general behaviour was similar but represented changes in patterns of plant responses throughout the experimental period: summer 1 (January to March, 2007), autumn/winter (April to August, 2007), early spring (September to mid-November, 2007), late spring (mid-November to December, 2007) and summer 2 (January to midApril, 2008). Herbage samples were harvested using a 0.90 $\times 0.37 \mathrm{~m}\left(0.333 \mathrm{~m}^{2}\right)$ metallic frame, which was randomly placed on three areas of the paddocks that represented the average sward condition at the time of sampling (visual assessment of sward height and herbage mass). All herbage within the frame was cut to ground level and taken to the laboratory, where their fresh weight was determined. After weighing, the three samples per paddock were combined and separated into two subsamples, one for dry matter (DM) content determination and other for manual dissection into leaf (leaf laminae), stem (leaf sheath + stem) and dead material. Morphological components were dried in forced draught oven at $65^{\circ} \mathrm{C}$ until constant weight, and the results used to calculate sward herbage mass ( $\left.\mathrm{kg} \mathrm{ha}^{-1} \mathrm{DM}\right)$ and morphological composition as percentage of total herbage mass. Total herbage bulk density $\left(\mathrm{kg} \mathrm{ha}^{-1} \mathrm{~cm}^{-1}\right)$ was then calculated as the ratio between herbage mass and average sward height. Similar procedure was used to calculate morphological components bulk density using the mass of each individual morphological component instead.

Sward structure was evaluated in a monthly basis using an inclined point quadrat (Warren-Wilson, 1960). The equipment was placed on areas that were representative of sward condition at the time of sampling (visual assessment of sward height and herbage mass). Measurements consisted of the introduction of the graduated stem throughout the vertical profile of the sward in a $32.5^{\circ}$ angle from the top towards the base. Along the trajectory, as the tip of the stem touched different plant parts, each contact was recorded specifying the morphological component touched and the corresponding reading at the scale. A last reading on the equipment scale was recorded when the tip of the stem reached the ground, which was used as reference to calculate the real height of the previous contacts. A minimum of 100 contacts per paddock was used, totalling 400 contacts per treatment. Data was sorted into $1-\mathrm{cm}$ strata and pooled in order to represent the same five seasons of the year used to harvest samples for determining herbage mass and morphological composition.

Monitoring of tiller population density was performed in a monthly basis and corresponded to counts of the total number of tillers within three $1.0 \times 0.25 \mathrm{~m}$ metallic frames randomly placed on representative areas of the paddocks at the time of sampling (visual assessment of height and herbage mass). Tillers were also separated into basal and aerial, with reproductive ones (visible flower heads) counted separately.

Data were analysed as repeated measures using the Mixed Procedure (Littel et al., 1996) of SAS ${ }^{\circledR}$ (Statistical Analysis System). The choice of the covariance matrix was made using the Akaike Information Criterion (AIC) (Wolfinger, 1993). Growth rhythm, season of the year

Table 1 - Stocking rate of continuously stocked marandu palisadegrass managed at $30 \mathrm{~cm}$ and subjected to nitrogeninduced rhythms of growth from January 2007 to April 2008

\begin{tabular}{|c|c|c|c|c|}
\hline \multicolumn{5}{|c|}{ Growth rhythms $\left(\mathrm{kg} \mathrm{ha}^{-1}\right.$ of $\left.\mathrm{N}\right)$} \\
\hline Season of the year & Non-fertilised & 150 & 300 & 450 \\
\hline & 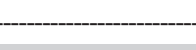 & - & & \\
\hline Summer 1 & 1.6 & 3.2 & 3.4 & 4.2 \\
\hline Autumn/Winter & 0.7 & 0.3 & 0.7 & 0.6 \\
\hline Early Spring & 0.4 & 0.8 & 1.1 & 1.4 \\
\hline Late Spring & 2.5 & 3.6 & 3.7 & 4.1 \\
\hline Summer 2 & 2.3 & 5.1 & 5.6 & 5.2 \\
\hline
\end{tabular}

Summer 1 (January to March, 2007), autumn/winter (April to August, 2007), early spring (September to mid-November, 2007), late spring (mid-November to December, 2007) and summer 2 (January to mid-April, 2008).

Sci. Agric. (Piracicaba, Braz.), v.67, n.5, p.531-539, September/October 2010 
and their interaction were considered fixed effects and blocks and its interactions considered random effects. Means were estimated using the "LSMEANS" command and comparisons made with Student $t$ test with a 5\% significance level. When appropriate, data were also subjected to regression analysis using the PROC REG of the same statistical package.

\section{Results}

Total herbage bulk density (TBD) varied with growth rhythm $(p=0.0024)$ and season of the year $(p<0.0001)$ (Table 2). Lowest values of TBD were recorded during summer 1 and highest during early spring, with similar
( $p>0.05)$ intermediate values recorded during autumn/ winter, late spring and summer 2 . Swards subjected to the fastest rhythms of growth (fertilised with 300 and 450 $\mathrm{kg} \mathrm{ha}{ }^{-1}$ of N) had the largest values of TBD, and no difference was recorded between swards subjected to slower rhythms of growth (non-fertilised or fertilised with $150 \mathrm{~kg} \mathrm{ha}^{-1}$ of N) ( $\left.p>0.05\right)$.

Leaf bulk density (LBD) varied with growth rhythm $(p<0.0001)$, season of the year $(p<0.0001)$ and growth rhythm $x$ season of the year interaction $(p=0.0189)$. With the exception of summer 1 , time of the year when variations in LBD were small between growth rhythms, largest values of LBD were recorded on swards subjected to the fastest rhythms of growth (fertilised with 300 and

Table 2 - Total herbage bulk density of continuously stocked marandu palisadegrass managed at $30 \mathrm{~cm}$ and subjected to nitrogen-induced rhythms of growth from January 2007 to April 2008.

\begin{tabular}{lccccc}
\hline \multicolumn{5}{c}{ Growth rhythms $\left(\mathrm{kg} \mathrm{ha}^{-1}\right.$ of N$)$} \\
\hline Season of the year & Non-fertilised & 150 & 300 & 450 & Mean \\
\hline & 303.8 & 273.5 & 334.2 & 303.9 & $303.9 \mathrm{C}$ \\
Summer 1 & 365.6 & 385.7 & 401.1 & 419.9 & $393.1 \mathrm{~B}$ \\
Autumn/Winter & 361.1 & 409.2 & 440.5 & 490.5 & $425.3 \mathrm{~A}$ \\
Early Spring & 339.5 & 343.6 & 385.0 & 411.4 & $369.9 \mathrm{~B}$ \\
Late Spring & 320.5 & 414.1 & 401.7 & 423.2 & $389.8 \mathrm{~B}$ \\
Summer 2 & $338.1 \mathrm{c}$ & $365.2 \mathrm{bc}$ & $392.5 \mathrm{ab}$ & $409.8 \mathrm{a}$ & \\
Mean & & & &
\end{tabular}

${ }^{\mathrm{Aa}}$ Means followed by the same lower case letters in lines and upper case letters in columns are not different $(p>0.05)$.

Table 3 - Morphological components bulk density of continuously stocked marandu palisadegrass managed at $30 \mathrm{~cm}$ and subjected to nitrogen-induced rhythms of growth from January 2007 to April 2008.

\begin{tabular}{|c|c|c|c|c|c|}
\hline \multirow{2}{*}{ Season of the year } & \multicolumn{4}{|c|}{ Growth rhythms $\left(\mathrm{kg} \mathrm{ha}^{-1}\right.$ of $\left.\mathrm{N}\right)$} & \multirow{2}{*}{ Mean } \\
\hline & Non-fertilised & 150 & 300 & 450 & \\
\hline & \multicolumn{4}{|c|}{ Leaf bulk density $\mathrm{kg} \mathrm{ha}^{-1} \mathrm{~cm}^{-1}$} & \\
\hline Summer I & $80.3 \mathrm{Aab}$ & $70.1 \mathrm{Ab}$ & $90.5 \mathrm{ABa}$ & $85.5 \mathrm{BCab}$ & $81.6 \mathrm{~A}$ \\
\hline Autumn/Winter & $54.8 \mathrm{Bd}$ & $71.1 \mathrm{Ac}$ & $87.3 \mathrm{Ab}$ & $102.8 \mathrm{Aa}$ & $79.0 \mathrm{~A}$ \\
\hline Early Spring & $30.4 \mathrm{Cc}$ & $49.4 \mathrm{Bb}$ & $55.8 \mathrm{Cb}$ & $80.8 \mathrm{BCa}$ & $54.1 \mathrm{C}$ \\
\hline Late Spring & $52.1 \mathrm{Bb}$ & $61.5 \mathrm{ABb}$ & $76.3 \mathrm{Ba}$ & $76.5 \mathrm{Ca}$ & $66.6 \mathrm{~B}$ \\
\hline \multirow[t]{2}{*}{ Summer II } & $59.1 \mathrm{Bb}$ & $60.6 \mathrm{ABb}$ & $82.6 \mathrm{ABa}$ & $94.4 \mathrm{ABa}$ & $74.2 \mathrm{AB}$ \\
\hline & \multicolumn{4}{|c|}{ Stem bulk density $\mathrm{kg} \mathrm{ha}^{-1} \mathrm{~cm}^{-1}$} & \\
\hline Summer I & 104.2 Aa & $112.1 \mathrm{Aa}$ & $119.2 \mathrm{ABa}$ & $109.3 \mathrm{BCa}$ & $111.2 \mathrm{~A}$ \\
\hline Autumn/Winter & $93.1 \mathrm{ABb}$ & $93.0 \mathrm{Ab}$ & $110.9 \mathrm{ABab}$ & $128.3 \mathrm{ABa}$ & $106.3 \mathrm{~A}$ \\
\hline Early Spring & 41.5 Dc & $69.3 \mathrm{Bbc}$ & $126.9 \mathrm{Aa}$ & 107.7 Cab & $86.3 \mathrm{~B}$ \\
\hline Late Spring & $65.4 \mathrm{Cb}$ & $69.1 \mathrm{Bb}$ & $99.3 \mathrm{Ba}$ & $107.8 \mathrm{BCa}$ & $85.4 \mathrm{~B}$ \\
\hline \multirow[t]{2}{*}{ Summer II } & $80.1 \mathrm{BCc}$ & $101.4 \mathrm{Abc}$ & 117.2 ABab & $138.8 \mathrm{Aa}$ & $109.4 \mathrm{~A}$ \\
\hline & \multicolumn{4}{|c|}{ Dead material bulk density $\mathrm{kg} \mathrm{ha}^{-1} \mathrm{~cm}^{-1}$} & \\
\hline Summer I & 119.2 & 91.3 & 124.5 & 109.1 & $111.0 \mathrm{D}$ \\
\hline Autumn/Winter & 217.7 & 221.6 & 202.8 & 188.9 & $207.8 \mathrm{BC}$ \\
\hline Early Spring & 289.1 & 290.5 & 257.8 & 302.0 & $284.8 \mathrm{~A}$ \\
\hline Late Spring & 221.9 & 212.9 & 209.4 & 227.1 & $217.8 \mathrm{~B}$ \\
\hline Summer II & 210.8 & 221.6 & 196.9 & 175.9 & 201.3 C \\
\hline
\end{tabular}

Aa Means followed by the same lower case letters in lines and upper case letters in columns are not different $(p>0.05)$.

Sci. Agric. (Piracicaba, Braz.), v.67, n.5, p.531-539, September/October 2010 
$450 \mathrm{~kg} \mathrm{ha}^{-1}$ of $\mathrm{N}$ ) (Table 3). Early spring was the season of the year when the lowest values of LBD were recorded. Similarly, stem bulk density (SBD) also varied with growth rhythm $(p<0.0263)$, season of the year $(p<0.0001)$ and growth rhythm $x$ season of the year interaction $(p=0.0002)$. Swards subjected to the fastest growth rhythms showed the largest values of SBD, except in summer 1 . There was no difference in SBD between non-fertilised and swards fertilised with $150 \mathrm{~kg} \mathrm{ha}^{-1}$ of $\mathrm{N}$ throughout the experimental period $(p>0.05)$ and, overall, lowest values of SBD were recorded during early and late spring. Dead material bulk density (DMBD) varied only with season of the year $(p<0.0001)$, with highest values recorded in early spring and lowest during summer 1 and 2.

Data from measurements using the inclined point quadrat regarding the distribution of morphological components of herbage mass along $10 \mathrm{~cm}$-strata of sward vertical profile are shown in Figure 3. The bottom strata $(0-10 \mathrm{~cm})$ had larger proportion of dead material relative to the middle and top strata. In this stratum the proportion of contacts in each of the morphological components increased with the acceleration of the growth rhythm of plants using nitrogen fertiliser. On average, the $0-10 \mathrm{~cm}$ strata concentrated 5,13 and $31.5 \%$ of all contacts in leaf, stem and dead material along the vertical profile of the swards, respectively. The middle strata $(10-20 \mathrm{~cm})$ had the largest proportion of contacts in the
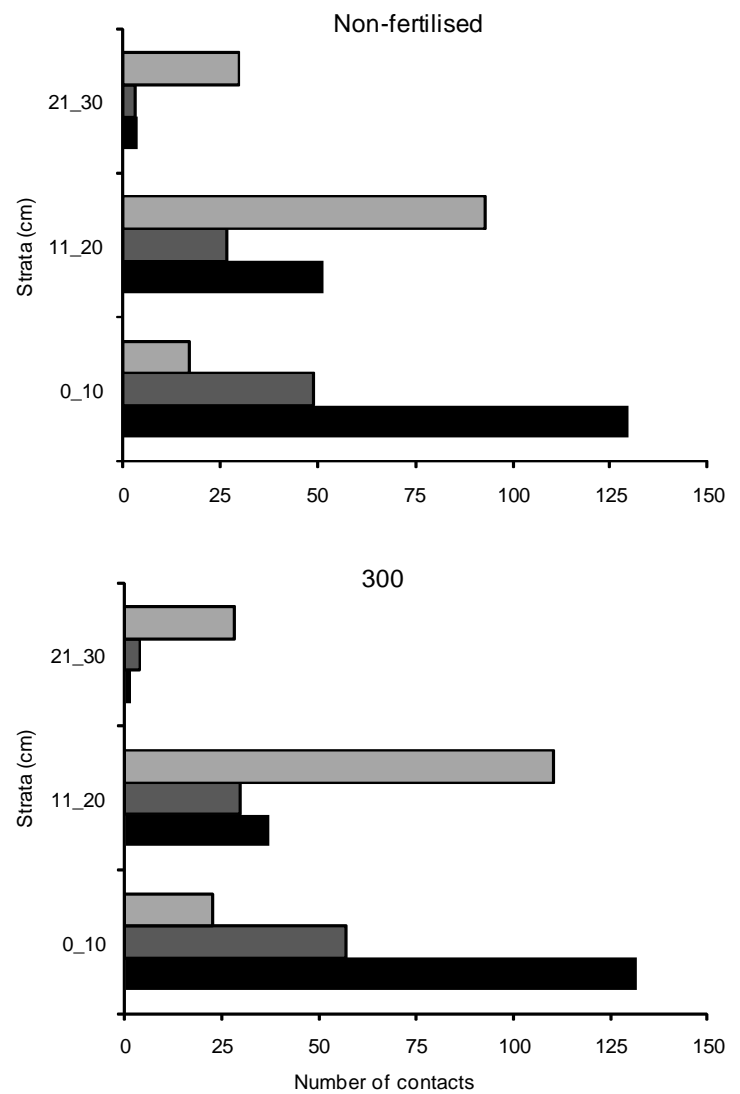

leaf component. On average, $68.2 \%$ of all contacts were in leaves, and acceleration of the growth rhythm of plants by nitrogen fertiliser application resulted in increased proportion of contacts in leaves (23.1, 24.4, 26.1 and $26.9 \%$ for non-fertilised swards and swards fertilised with 150, 300 and $450 \mathrm{~kg} \mathrm{ha}^{-1}$ of $\mathrm{N}$, respectively). In the top strata the main morphological component present was leaf, whose proportion of contacts did not vary with acceleration of growth rhythm of plants, but decreased for dead material $(2.1,1.7,1.0$ and $0.3 \%$ for non-fertilised swards and swards fertilised with 150, 300 and $450 \mathrm{~kg}$ $\mathrm{ha}^{-1}$ of $\mathrm{N}$, respectively).

During the rainy season (late spring and summer A), the top $50 \%$ of sward height was comprised mainly of leaves regardless of growth rhythm. Stem and dead material components were mainly concentrated in the lower strata, close to ground level, with swards subjected to the fastest rhythms of growth (fertilised with 300 and $450 \mathrm{~kg} \mathrm{ha}^{-1}$ of N) showing a slightly smaller concentration than those subjected to slowest rhythms of growth (non-fertilised or fertilised with $150 \mathrm{~kg} \mathrm{ha}^{-1}$ of $\mathrm{N}$ ) (Figure 4). During the dry season (autumn/winter and early spring - B), the proportion of leaves in the top part of the sward was larger on those subjected to the fastest relative to the slowest rhythms of growth. On these swards, stem and dead material represented up to 35 and $45 \%$ of the top strata, respectively.
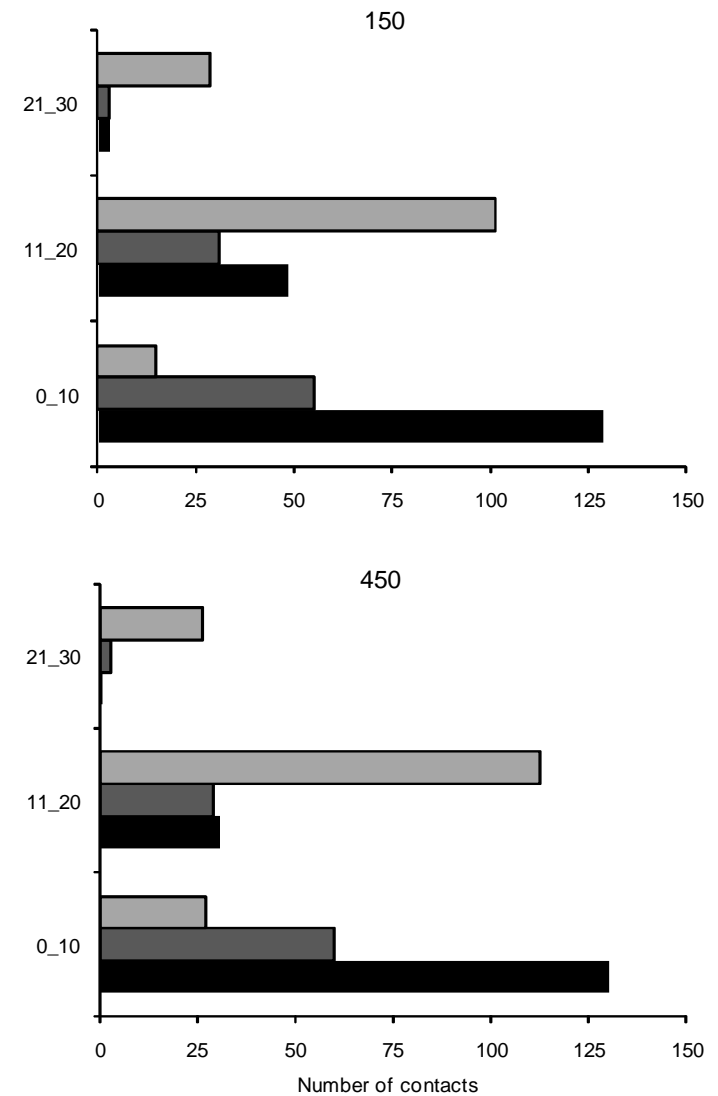

Figure 3 - Number of contacts on morphological components - leaf, stem and dead material - in each $10 \mathrm{~cm}$ - stratum of marandu palisadegrass subjected to continuous stocking and nitrogen-induced rhythms of growth from January 2007 to April 2008. 
A

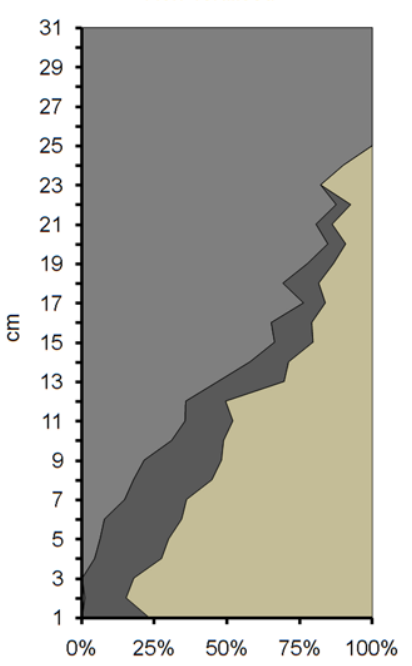

150

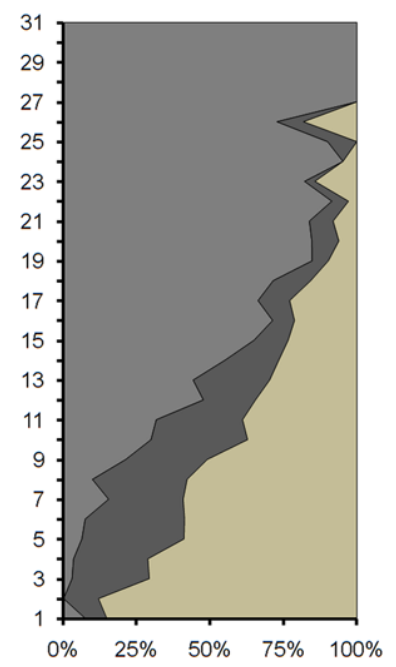

300

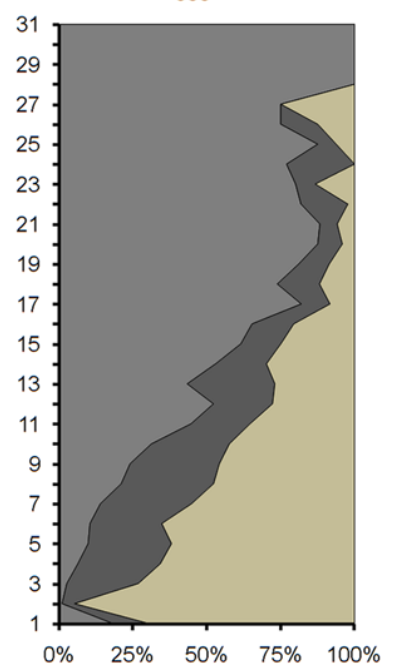

450

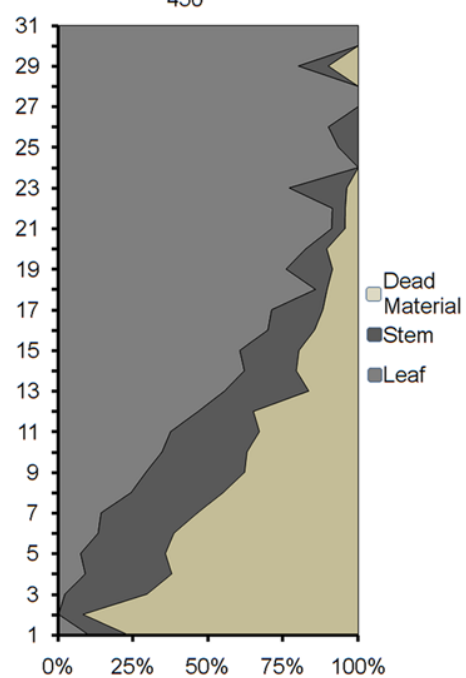

Proportion of components
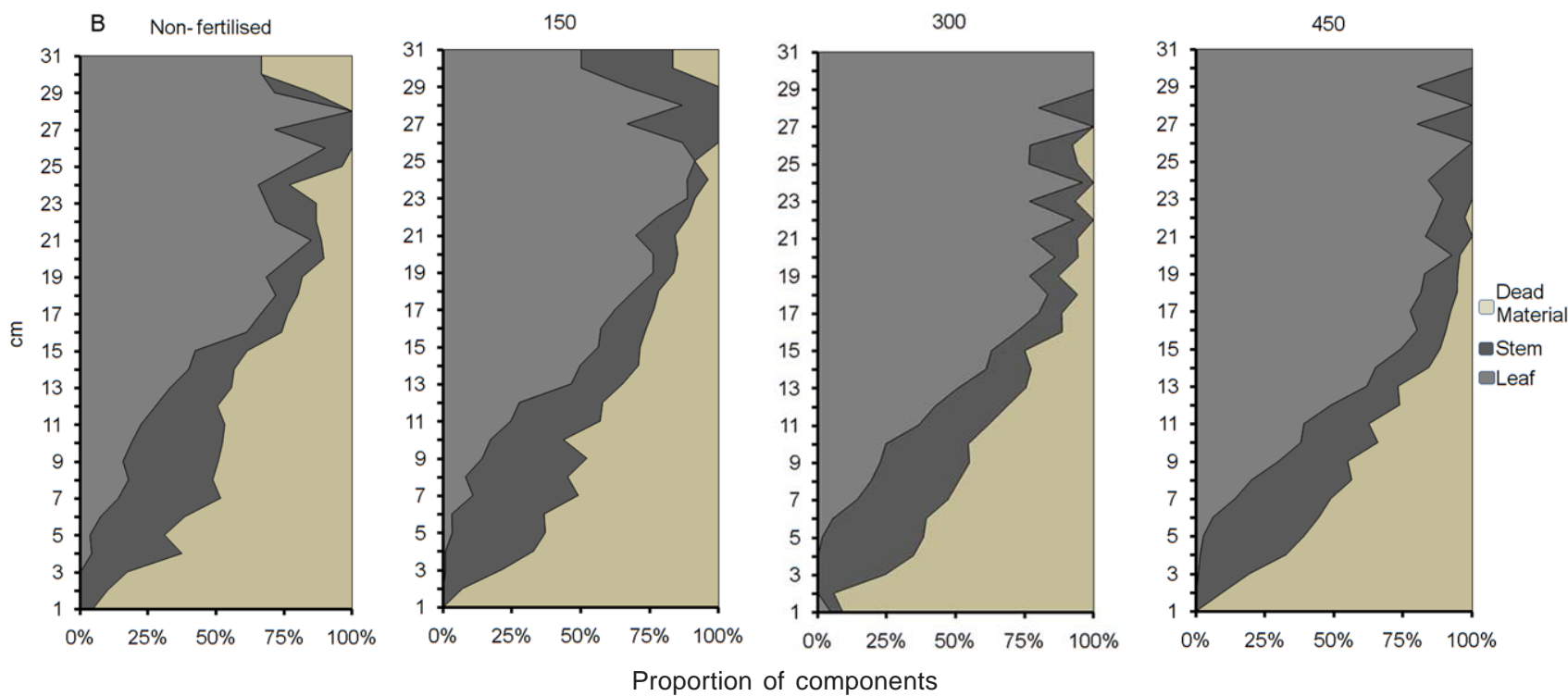

Proportion of components

Figure 4 - Spatial distribution of morphological components during the rainy (A) and the dry (B) seasons of the year of marandu palisadegrass subjected to continuous stocking and nitrogen-induced rhythms of growth from January 2007 to April 2008. (A) Rainy season comprises pooled data from summer I, late spring and summer II; (B) Dry season comprises pooled data from autumn/winter and early spring.

\section{Discussion}

Sward structure is formed as a result of morphological and physiological modifications that occur on both individual tillers and tiller population. These are associated with morphogenetic responses of individual tillers to defoliation and with changes in patterns of tiller appearance and death in response to competition for light and other environmental growth factors within sward canopy (Lemaire and Chapman, 1996). Grazing management strategies should be used as a means of generating a sward structure that would allow for positive responses in terms of herbage accumulation and animal performance (Hodgson and Da Silva, 2002). In order to achieve that it is necessary to identify sward targets (Hodgson, 1990) associated with optimum balance between apparently conflicting processes ( $\mathrm{Da}$ Silva and Nascimento Júnior, 2007b). The results of grazing experiments carried out using tropical forage grass species following similar methodology to those used with temperate forage grass species have demonstrated that sward height can be used as target (Hodgson, 1985) with the advantage of being easy to measure and relate to in field conditions (Hodgson and Da Silva, 2002). The target of sward height used in this experiment was chosen based on the results of previous experiments by the research group that showed an optimum balance between herbage accumulation and animal performance on swards maintained at $30 \mathrm{~cm}$. However, 
for the same target of sward height, acceleration of the growth rhythm of plants using nitrogen fertiliser resulted in increased total herbage bulk density. This may be the result of the higher rates of leaf elongation on nitrogen fertilised relative to non-fertilised swards (Mazzanti et al., 1994). This was corroborated by the results of a concomitant experiment carried out in the same area involving measurements of morphogenetic responses to treatments imposed (Table 4).

Gastal and Nelson (1994) commented that nitrogen can generate a three to four fold increase in leaf elongation rate (LER), suggesting that this is the main morphogenetic response to nitrogen fertiliser application. Although LER is the characteristic determining acceleration of the growth rhythm of plants, tiller population density (TPD) plays an important role in increasing herbage bulk density and herbage mass on nitrogen fertilised swards (Fagundes et al., 2006; Mesquita et al., 2010). Nitrogen application increases the proportion of growing tillers and, consequently, augments the tillering process (Cruz and Boval, 2000). Such pattern of response was reported by Duru and Ducroq (2000) for Dactylis glomerata L. and by Fagundes et al. (2006) for Brachiaria decumbens Stapf. cv. Basilisk.

The potential tiller population density for each grass species is related to its rate of leaf appearance (LAR), since there is an axillary bud for each new produced leaf that may or may not develop into a new tiller depending on environmental and management conditions. Nitrogen influences the release of dormant buds and accelerates tissue flows in individual tillers, increasing the turnover of leaves and tillers in the sward, resulting in younger profile of the tiller population. This, in turn, favours the herbage accumulation process, since young tillers have higher rates of leaf appearance and elongation (Bullock et al., 1994) and produce higher nutritive value herbage (Santos et al., 2006) than old tillers. In the present experiment, the higher LAR on swards subjected to faster rhythms of growth resulted in higher tiller population density (Table 4). These results explain the increase in leaf (LBD) and stem (SBD) bulk density with increasing rhythms of growth (Table 3) and the relatively stable values of dead material bulk density (DMBD). Although LBD and SBD increased with the increase in growth rhythm of plants, the proportion between these two morphological components in sward herbage mass did not vary significantly, with values of the LBD:SBD ratio of $0.72,0.70,0.68$ and 0.74 for non-fertilised and swards fertilised with 150, 300 and $450 \mathrm{~kg} \mathrm{ha}{ }^{-1}$ of $\mathrm{N}$, respectively. In a concomitant experiment in the same area, Mesquita et al. (2010) found that the acceleration of the growth rhythm of plants by nitrogen application triggered an important plastic response in terms of herbage accumulation characterised by proportional increments in the proportion of leaf and stem in sward herbage mass and small changes in sward structure, suggesting a "compensating mechanism" of sward responses to variations in growth rhythm when subjected to steady state management conditions.

Although the ratio between leaf and stem remained relatively stable, acceleration of the growth rhythm of plants resulted in increased sward leaf area index (LAI) (Table 4). Such a result involves dynamic aspects of responses on both individual tillers and tiller population, as reported by Chapman and Lemaire (1993) for temperate forage grass species. For tropical grass species the general pattern of responses is the same, only changing the relative importance of specific characteristics, particularly stem elongation ( $\mathrm{Da}$ Silva, 2004). Plants have three possibilities to invest and form LAI: tiller population density, number of leaves per tiller and leaf size (area) (Matthew et al., 2000). Fricke et al. (1997) and Matthew et al. (2000) suggest that nitrogen supply increases the flux of cells from leaf growing zones, increasing LER and length of fully expanded leaves which, in association with the faster growth rhythm of individual tillers and patterns of tiller appearance and death, results in a larger population with high proportion of young tillers. These grow faster and are more responsive to nitrogen application, resulting in higher values of sward LAI throughout the year.

Variation in spatial distribution of the morphological components of the swards was small (Figure 3), with differences being detected only in terms of bulk density $\left(\mathrm{kg} \mathrm{ha} \mathrm{c}^{-1} \mathrm{~cm}^{-1} \mathrm{DM}\right)$ in different sward strata, a result in keeping with those of total herbage bulk density. In spite of the small variation in spatial distribution of the morphological components along the vertical profile of the swards, those subjected to the slower rhythms of growth (non-fertilised or fertilised with $150 \mathrm{~kg} \mathrm{ha}^{-1}$ of N) had a more vertical architecture (higher foliage angle) than those subjected to faster rhythms of growth (fertilised with 300 and $450 \mathrm{~kg} \mathrm{ha}^{-1}$ of N) (Mesquita et al., 2010).

Table 4 - Relationship between nitrogen application rate and morphogenetic and structural responses of continuously stocked marandu palisadegrass managed at $30 \mathrm{~cm}$ and subjected to nitrogen-induced rhythms of growth from January 2007 to April 2008.

\begin{tabular}{llcc}
\hline Response & \multicolumn{1}{c}{ Regression } & $\mathrm{R}^{2}(\%)$ & Significance \\
\hline Leaf elongation rate (leaves tiller ${ }^{-1}$ day $\left.^{-1}\right)$ & $\mathrm{Y}=0.8603+0.001 * \mathrm{~N}$ & 87.4 & $p<0.0001$ \\
\hline Leaf appearance rate (leaves tiller $\left.{ }^{-1} \mathrm{day}^{-1}\right)$ & $\mathrm{Y}=0.0515+0.00005 * \mathrm{~N}$ & 89.7 & $p<0.0001$ \\
Length of fully expanded leaves $(\mathrm{cm})$ & $\mathrm{Y}=17.9+0.0086 * \mathrm{~N}$ & 87.0 & $p<0.0001$ \\
Stem length $(\mathrm{cm})$ & $\mathrm{Y}=21.1$ & - & $p>0.05$ \\
Tiller population density (tillers $\left.\mathrm{m}^{-2}\right)$ & $\mathrm{Y}=804.3+1.0071 * \mathrm{~N}$ & 70.0 & $p<0.01$ \\
Leaf area index (LAI) & $\mathrm{Y}=2.054+0.0049 * \mathrm{~N}$ & 89.9 & $p<0.0001$ \\
\hline
\end{tabular}

Sci. Agric. (Piracicaba, Braz.), v.67, n.5, p.531-539, September/October 2010 
Modifications in foliage angle are a result of variations in the arrangement of morphological components in both vertical and horizontal dimensions of the sward, consisting in an important structural response, particularly to competition for light. The results suggest that as the growth rhythm of plants is accelerated by nitrogen application, there is an increase in sward herbage mass and total herbage bulk density and a decrease in foliage angle (Millen and McClendon, 1979) as a means of maintaining sward structure relatively stable (Figure 3).

Modifications in sward structure also occur as a result of seasonal variations in tiller population and rates of morphogenetic processes on individual tillers. Grant et al. (1983) stated that seasonal variation in solar radiation and sward herbage mass are the main determinants of tiller population density, indicating that tiller population is frequently being adjusted. The persistency and productivity of grass swards are directly dependent of the combined effect of tiller appearance and death (Matthew et al., 2000). These patterns vary with grass species and defoliation management imposed. In this experiment sward structure clearly varied with the seasonal distribution of climatic factors of growth (Figure 4). In general, sward herbage mass and herbage bulk density increased over autumn/winter and early spring as a result of increased accumulation of dead material at the lower strata of the swards, since the there was a corresponding decrease in bulk density of leaves and stems (Table 3). Such response was consequence of the low stocking rates used to maintain swards on target (Table 1). Considering that tiller appearance rate is significantly reduced and morphogenetic processes limited by the low availability of environmental growth factors (Matthew et al., 2000), particularly light and rainfall, tiller death is increased, especially in early spring, causing reduction of sward LAI during that time of the year. During the period of low rainfall and light availability, swards subjected to the faster rhythms of growth were capable of maintaining upper strata with larger proportion of leaves in relation to those subjected to slower rhythms of growth (Figure 4B). This could represent an advantage in the sense that would allow the return of $s w a r d s$ to production earlier in the new pasture growing season by favouring tissue turnover and LAI restoration. However, when sward structure is considered during times of the year with no restrictions in the availability of climatic growth factors (Figure 4A), there was no variation in the proportion of morphological components along the vertical profile of swards, a likely result of the efficient adjustment in stocking rate carried out to maintain swards on target (Figure 2).

Overall, the results confirm the statements of Hodgson and Da Silva (2002) and Da Silva (2004) that it is possible to achieve high herbage production and high animal performance when management requirements of plants are taken into account. There is a range of sward targets for continuously stocked marandu palisadegrass (20 to $40 \mathrm{~cm}$ ) within which it is possible to maintain a relatively stable high herbage production and distinct levels of animal performance and herbage utilisation (Da Silva and Nascimento Júnior, 2007a). High animal performance would be attainable closer to the upper end and high animal productivity closer to lower end of the range, the decision of each target to use depending on specific characteristics, objectives and systems profile. Within this range of sward targets maintained under a steady state condition, acceleration of the growth rhythm of plants with nitrogen fertiliser did not modify the vertical distribution of morphological components of the sward. However, it promoted improvements in morphological composition of sward herbage mass characterised by increases in leaf and stem bulk density and in sward LAI. These conditions may result in higher levels of productivity, since there must be a corresponding increase in stocking rate and, possibly, an increase in animal performance.

\section{Conclusion}

Acceleration of the growth rhythm of continuously stocked marandu palisadegrass using nitrogen fertiliser generates increases in total herbage bulk density, particularly leaf and stem. These responses are mediated by the acceleration of tissue flows in individual tillers, represented by increases in rates of leaf appearance and elongation, and in the turnover of the tiller population, favouring high tiller population density. However, the vertical structure of the swards remains relatively stable within a considerable range of rhythms of growth, with differences being only a function of seasonal variations in climatic conditions.

\section{Acknowledgements}

To FAPESP for the sponsorship provided to the first author during her master degree programme.

\section{References}

Bullock, J.M.; Mortimer, A.M; Begon, M. 1994. Physiological integration among tillers of Holcus lanatus: age dependence and responses to clipping and competition. New Phytologist 128: 737-747.

Barthram, G.T. 1985. Experimental techniques: the HFRO sward stick. p. 29-30. In: Hill Farming Research Organization, Midlothian, Scotland.

Chapman, D.F.; Lemaire, G. 1993. Morphogenetic and structural determinants of plant regrowth after defoliation. p. 55-64. In: Baker, M.J., ed. Grasslands for our world. SIR, Wellington, New Zealand.

Cruz, P.; Boval, M. 2000. Effect of nitrogen on some morphogenetic traits of temperate and tropical perennial forage grasses. p. 151168. In: Lemaire, G.; Hodgson, J.; Moraes, A., eds. Grassland ecophysiology and grazing ecology. CABI, Wallingford. UK.

Da Silva, S.C. 2004. Understanding the dynamics of herbage accumulation in tropical grass species: the basis for planning efficient grazing management practices. In: Pizarro. E.; Carvalho, P.C.F.; Da Silva, S.C., eds. Proceedings of the Grassland Ecophysiology and Grazing Ecology 2, Curitiba, PR, Brazil. (in Portuguese, with abstract in English). 
Da Silva, S.C.; Nascimento Júnior, D. 2007a. Advances in research on tropical forage plants in pastures: physical and physiological characteristics and grazing management. Revista Brasileira de Zootecnia 36: 121-138 Suppl. (in Portuguese, with abstract in English).

Da Silva, S.C.; Nascimento Júnior, D. 2007b. Ecophysiology of livestock grazing and its implications on the performance and productivity of pastoral systems. p. 1-48. In: Proceedings of the Symposium of Strategic Management Pasture 4, Viçosa, MG, Brazil. (in Portuguese).

Duru, M.; Ducrocq, H. 2000. Growth and senescence of the successive leaves on a Cocksfoot tiller. Effect of nitrogen and cutting regime. Annals of Botany 85: 645-653.

Fagundes, J.L.; Fonseca, D.M.; Morais, R.V.; Mistura, C.; Vitor, C.M.T.; Gomide, J.A., Nascimento Júnior, D.; Santos, M.E.R.; Lambertucci, D.M. 2006. Evaluation of structural characteristics of the signalgrass in a nitrogen fertilized pasture over the seasons of the year. Revista Brasileira de Zootecnia 35: 30-37. (in Portuguese, with abstract in English).

Fricke, W.; McDonald, A.J.S.; Mattson-Djos, L. 1997. Why do leaves and cells leaf of N-limited barley elongate at reduced rates? Planta 202: 522-530.

Gastal, F.; Belanger, G.; Lemaire, G. 1992. A model of the leaf extension rate of tall fescue in response to nitrogen and temperature. Annals of Botany 70: 437-442.

Gastal, F.; Nelson, C.J. 1994. Nitrogen use within the growing leaf blade of tall fescue. Plant Physiology 105: 191-197.

Grant, S.A.; Barthram, G.T.; Torvell, L.; King, J.; Smith, H.K. 1983. Sward management, lamina turnover and tiller population density in continuously stocked Lolium perenne-dominated swards. Grass and Forage Science 38: 333-344.

Hodgson, J. 1985. The significance of sward characteristics in the management of temperate sown pastures. p. 63-66. In: International Grassland Congress 15, Kyoto, Japan.

Hodgson, J. 1990. Grazing Management-Science Into Practice. Essex, England, Longman Scientific and Technical.

Hodgson, J.; Da Silva, S.C. 2002. Options in tropical pasture management. p. 180-202. In: Sociedade Brasileira de Zootecnia [SBZ]. Proceedings of the Annual Meeting of the Brazilian Society of Animal Sciences 39. SBZ, Recife, PE, Brazil.

Laca, E.A.; Lemaire, G. 2000. Measuring sward structure. p. 103121. In: Mannetje, L.; Jones, R.M., eds. Field and laboratory methods for grassland and animal production research. CABI, Wallingford, UK.
Lemaire, G.; Chapman, D. 1996. Tissue fluxes in grazing plant communities. p. 3-36. In: Hodgson, J.; Illius, A.W., eds. The ecology and management of grazing systems. : CABI, Wallingford, UK.

Littell, R.C.; Milliken, G.A.; Stroup, W.W.; Wolfinger, R.D. 1996. SAS System for Mixed Models. SAS Institute, Cary, NC, USA. $633 \mathrm{p}$.

Mazzanti, A; Lemaire, G.; Gastal, F. 1994. The effect of nitrogen fertilization upon the herbage production of tall fescue swards continuously grazed with sheep. 1. Herbage growth dynamics. Grass and Forage Science 49: 352-359.

Matthew, C.; Assuero, S. G.; Black, C. K.; Sackville Hamilton, N. R. 2000. Tiller dynamics of grazed swards. p. 127-150. In: Lemaire, G.; Hodgson, J.; Moraes, A., eds. Grassland ecophysiology and grazing ecology. CABI, Wallingford, UK.

Mesquita, P.; Da Silva, S.C.; Paiva, A.J.; Caminha, F.O.; Pereira, L.E.T.; Guarda, V.D.; Nascimento Júnior, D. 2010. Structural characteristics of marandu palisadegrass swards subjected to continuous stocking and contrasting rhythms of growth. Scientia Agricola 67: 23-30.

Millen, G.G.; McClendon, J.H. 1979. Leaf angle: an adaptative feature of sun and shade leaves. Botanical Gazette 140: 437- 442.

Raij, B.van.; Quaggio, J.A. 1983. Methods of Soil Analysis for Fertility. IAC, Campinas, SP, Brazil. 31 p. (Technical Report 81). (in Portuguese).

Santos, P.M.; Corsi, M.; Pedreira, C.G.S; Lima, C.G. 2006. Tiller cohort development and digestibility in Tanzania guinea grass (Panicum maximum cv. Tanzania) under three levels of grazing intensity. Tropical Grassland 40: 84-93.

Warren-Wilson, J. 1960. Inclined point quadrat. New Phytologist 58: 92-101.

Wolfinger, R.D. 1993. Covariance structure selection in general mixed models. Communications in Statistics Simulation and Computation, 22: 1079-1106.

Received September 02, 2009

Accepted May 14, 2010 